\title{
OCCURRENCE OF TRUE SPIDERS ASSOCIATED WITH WHEAT PLANTS IN QALUOBIA AND BENI-SUIEF GOVERNORATES, EGYPT
}

\author{
Hosnea A. A. Elwan \\ Plant Protection research Institute, Agricultural Research center, Dokki, Giza, Egypt \\ Received: Mar. 28,2019 \\ Accepted: May. 22, 2019
}

\begin{abstract}
Wheat, (Triticum aestivum L.), is a major cereal crop in Egypt. True spiders represent one of the most important natural predators against different arthropod pests in Egyptian fields. In this study, the common true spiders were surveyed in wheat fields, and counted weekly using two different methods (Plantshaking method and Pit-fall trap) during the cultivated seasons 2016/2017 and 2017/2018. The obtained results indicated that the collected spiders associated with wheat plants in the two tested localities (Qaluobia and Beni-Suief governorates) were 13 spider species belongs to 12 genera in 12 families. The number of collected spider species associated with foliage in this study were 10 species, as the soil spiders were 4 (one of them inhabiting foliage and soil (Erigone $\mathrm{sp}$ : Linyphidae). The abundance of the collected species were higher during April month along the two cultivated seasons. The results indicated that the commonest spiders inhabiting the soil of wheat plants in Qaluobia Governorate were belonging to 3 families, Gnaphosidae, Lycosidae and Oecobiidae. The highest number of collected spider species were observed during April 2017 and 2018 but the period of December did not recorded any spiders. Family Gnaphosidae recorded the highest population followed by Lycosidae and Oecobiidae along the two examined seasons.
\end{abstract}

Key words: Wheat, true spiders, wheat, population, identification.

\section{INTRODUCTION}

Wheat, (Triticum aestivum L.) is a major cereal crop not only in Egypt but also worldwide. It gained a particular importance as the most available winter cereal crop. Most of previous investigations of the wheat insect pests have been largely directed towards the common insects infesting this crop such as aphids, wheat stem sawfly, the lesser grain borer and the rice weevil. True spiders (Araneae) represent by far the largest order of the arachnids, with about 35,000 species known worldwide. All are carnivorous predators with powerful fangs, called chelicerae, which are used to bite and crush the prey and to inject venom. However, Wise (1993) stated that spiders are generalist feeders that attack insects and other arthropods. They are even more strictly carnivorous that have many other tasks of primarily predacious invertebrates such as carbide beetles. Many of the spiders commonly found in Egyptian fields, particularly members of the families of Lycosidae, Philodromidae, Salticidae and Scytodidae are considered beneficial natural enemies. Many authors who are related to biological control field of insect pests mentioned true spiders as important predators within their works of survey. They are capable of reducing populations of herbivores that may not be limited by competition and food availability in some agroecosystems (Sunderland 1999). Another review of an abundant spider in agroecosystems, Oxyopes salticus Hentz, indicated the 
considerable potential of this species for suppressing insect pest populations in agroecosystems (Young and Lockley 1985). These reviews and others increasingly point to the importance of spiders as part of a strategy of Integrated Pest Management. Many field experiments, performed over the last 35 years, have demonstrated that spiders can reduce insect populations and the crop damage they cause (Mansour et al., 1980; Mansour and Whitcomb 1986; Oraze and Grigarick 1989; Carter and Rypstra 1995; Riechert and Lawrence 1997).The Effect of organic fertilizers and flowering plants on sheet-web and wolf spider populations (Araneae: Lycosidae and Linyphiidae) and its importance for pest control was studied by El-Nabawy et al. (2016).The authors noticed that the numbers of Collembola, thirps, and lycosid and linyphiid spiders were higher on flowering plants recieved organic fertilizer compared with that received chemical fertilizers. An analysis of 29 faunal surveys of spiders found in nine field crops in the United States indicates the presence of 614 species in 192 genera and 26 families. These species represent $19 \%$ of the total of 3311 species occurring in North America. Five families included $61 \%$ of the species reported in field crops: Salticidae (89 spp.), Linyphiidae (78 spp), Araneidae (77spp), Therididae (64spp), and Lycosidae (62spp) Young and Edwards (1990).

The present study was conducted to study the occurrence of true spiders in wheat fields in Qaluobia and Beni Suief Governorates during the period of December to April months for two seasons.

\section{MATERIALS AND METHODS}

Survey of true spiders:

Survey of the common true spiders found in wheat fields was done in
Qaluobia (Qaha region) and Beni-Suief (Seds region) Governorates during 2016/2017 and 2017/208 cultivated seasons, where the wheat plants were weekly investigated for true spiders and counted (early in the morning).

\section{Picking of the collected true spiders:}

Spiders were trapped by two methods:

\section{1- Plant-shaking method:}

The spiders on wheat foliage were collected by shaking the plants on a cloth or a shake sheet. This method is referred as the drop cloth method. Ten wheat plants were shacked over the shaking white cloth $(1 \mathrm{~m} \times 1 \mathrm{~m})$ twice monthly during the surveying period.

\section{2-Pit-fall trap method:}

Samples of the soil spiders fauna were collected from the study area by pitfall method described by Slingsby and Cook (1986) and Southwood and Henderson (2000). In this study, the number of spiders trapped in primarily depend on their location activity (Greenslade and Greenslade, 1983, and Mickhail, 1993). The traps were used in each sampling date in different plots according to Rizk et al. (2005). The number of spiders collected is the total number of individuals/10 traps to avoid decimal fraction. Plastic containers (10 $\mathrm{cm}$ diameter) were filled with detergent and water (1:40). In this way specimens that fall into the trap are died and preserved. The traps were embedded in the soil at the soil surface. Ten traps were distributed at the experimental wheat area (1/2 feddan). Trap catches were collected every two weeks and the old traps were replaced by new ones at the same place. Specimens are transported back to the laboratory alive or dead. 


\section{Identification of true spiders:}

In most cases the families are easy to distinguish in the field by position and number of eyes, overall shape, length of legs, and form of spinners (Wise, 1993, and sallam , 2002). In the laboratory it is easy to separate the kinds of true spiders which are morphologically similar and given a code number for each. Then, spiders were kept in a mixture of $70 \%$ alcohol and $5 \%$ glycerol until their identification.

\section{RESULTS AND DISCUSSION}

The study indicated that the collected spiders associated with wheat plants in the two tested localities (Qaluobia and Beni-Suief governorates) were 13 spider species belongs to 12 genera in 12 families (Table 1). The families are : Gnaphosidae, Araneidae, Miturgidae, Therididae, Lycosidae, Philodromidae, Oecobiidae, Salticidae, Thomisidae, Linyphidae, Tetragnathidae and Dictynidae. The number of collected spider species associated with foliage in this study were 10 species, as the soil spiders were 4 (one of them collected inhabiting foliage and soil i.e, Erigone sp. (Linyphidae). In this study, the abundance of the collected families was higher during April of both seasons.

Table (1): True spider species associated with wheat plants at Qaluobia and Beni-Suief Governorates, during 2016/2017 and 2017/208 seasons

\begin{tabular}{|c|c|c|c|c|}
\hline Family & Species & Habitat & Locality & Occurrence \\
\hline $\begin{array}{l}\text { Gnaphosidae } \\
\text { Pocock }\end{array}$ & Zelotes sp. & Soil & Q. & April \\
\hline $\begin{array}{l}\text { Araneidae } \\
\text { Simon }\end{array}$ & $\begin{array}{l}\text { Argiope trifasciata } \\
\text { Forskal }\end{array}$ & Foliage & Q. \& B. & April-May \\
\hline \multirow[t]{2}{*}{$\begin{array}{l}\text { Miturgidae } \\
\text { Simon }\end{array}$} & $\begin{array}{l}\text { Cheiracanthium isiacum } \\
\text { Cambridge }\end{array}$ & Foliage & Q. \& B. & March- April \\
\hline & C. pelasgicum (Koch) & Foliage & Q. \& B. & March- April \\
\hline $\begin{array}{l}\text { Therididae } \\
\text { Sundeval }\end{array}$ & Crustufina conspicus & Foliage & Q. & $\begin{array}{l}\text { February- } \\
\text { March }\end{array}$ \\
\hline $\begin{array}{l}\text { Lycosidae } \\
\text { Sundeval }\end{array}$ & Hogna ferox (Lucas) & Soil & Q. \& B. & $\begin{array}{l}\text { December- } \\
\text { February }\end{array}$ \\
\hline $\begin{array}{l}\text { Philodromidae } \\
\text { Thorell }\end{array}$ & $\begin{array}{l}\text { Thanatus albini } \\
\text { (Audouin) }\end{array}$ & Foliage & Q. \& B. & March- April \\
\hline $\begin{array}{l}\text { Oecobiidae } \\
\text { Blackwall }\end{array}$ & Oecobius sp. & Soil & Q. & January-April \\
\hline $\begin{array}{l}\text { Salticidae } \\
\text { Blackwall }\end{array}$ & $\begin{array}{l}\text { Plexippus paykulli } \\
\text { (Audouin) }\end{array}$ & Foliage & Q. \& B. & February-April \\
\hline $\begin{array}{l}\text { Thomisidae } \\
\text { Sundeval }\end{array}$ & $\begin{array}{ll}\text { Thomisus } & \text { spinifer } \\
\text { Cambridge } & \end{array}$ & Foliage & Q. \& B. & March- April \\
\hline \multirow{2}{*}{$\begin{array}{l}\text { Linyphidae } \\
\text { Blackwall }\end{array}$} & \multirow[t]{2}{*}{ Erigone sp. } & Foliage & Q. & April \\
\hline & & Soil & B. & March- April \\
\hline $\begin{array}{l}\text { Tetragnathidae } \\
\text { Menge }\end{array}$ & $\begin{array}{l}\text { Tetragnatha nilens } \\
\text { (Audouin) }\end{array}$ & Foliage & Q. \& B. & March- April \\
\hline $\begin{array}{l}\text { Dictynidae } \\
\text { Blackwall }\end{array}$ & Dictyna sp. & Foliage & Q. \& B. & March -April \\
\hline
\end{tabular}

Q. = Qaluobia B.= Beni-Suief Sample was consists of 10 wheat plants 
The current study showed that Qaluobia governorate was harbored more spiders than Beni-Suief governorate. The collected spiders in two tested regions collectively were Argiope trifasciata (Araneidae), Cheiracanthium isiacum and C. pelasgicum (Miturgidae), Hogna ferox (Lycosidae), Thanatus albini (Philodromidae), Plexippus paykulli (Salticidae) and Thomisus spinifer (Thomisidae), Tetragnatha nilens (Tetragnathidae) and Dictyna sp. (Dictynidae) Table (1). The same data showed that the collected spiders in Qaluobia Governorate and disappeared in Beni-Suief Governorate were Zelotes sp. (Gnaphosidae), Crustufina conspicus (Therididae), and Oecobius sp, (Oecobiidae).

The obtained data in Tables (2 and 3) show that the commonest spiders inhabiting soil of wheat plants in Qaluobia Governorate were belonging to 3 families, Gnaphosidae, Lycosidae and Oecobiidae. The highest number of collected spider families was observed during April 2017 and 2018 (52 and 60 individuals, respectively). However, the period of December 2016 did not recorded any population of the collected spiders. Also, the same tables indicated that the highest population of the collected families was determined for the family Gnaphosidae followed by Lycosidae and Oecobiidae during the two cultivated seasons.

In conclusion, the spiders species may play a buffer to regulate population of many mites and insect pests such as stem borer, maggots and leaf and plant hoppers. Thee beneficial role of spiders might be interpreted by the low populations of the pests when existed. Accordingly, conservation of these beneficial species are necessary to keep the natural balance in wheat fields as well in other ecosystem (Hendawy and AbulFadl, 2004). This could be mainly done by minimizing the application of any chemicals, Sallam (2002). Barrion and Litsinger (1980) and Nentwig (1987) reported that small pests, such as thirps, midge and aphids, may die by being eaten of caught in the webs of large spiders.

Table (2): Seasonal abundance of spiders/10 pit-fall traps in wheat fields at Qaluobia Governorate during 2016/2017 cultivated season.

\begin{tabular}{|l|c|c|c|c|}
\hline \multicolumn{1}{|c|}{ Month } & Gnaphosidae & Lycosidae & Oecobiidae & Total \\
\hline December 2016 & 0 & 0 & 0 & 0 \\
\hline January 2017 & 6 & 5 & 4 & 15 \\
\hline February 2017 & 8 & 5 & 3 & 16 \\
\hline March 2017 & 11 & 7 & 6 & 24 \\
\hline April 2017 & 22 & 17 & 13 & 52 \\
\hline
\end{tabular}

Table (3): Seasonal abundance of spiders/10 pit-fall traps in wheat fields at Qaluobia Governorate during 2017/2018 cultivated seasons.

\begin{tabular}{|l|c|c|c|c|}
\hline \multicolumn{1}{|c|}{ Month } & Gnaphosidae & Lycosidae & Oecobiidae & Total \\
\hline December 2017 & 1 & 0 & 0 & 1 \\
\hline January 2018 & 9 & 3 & 5 & 17 \\
\hline February 2018 & 12 & 4 & 7 & 23 \\
\hline March 2018 & 16 & 9 & 4 & 29 \\
\hline April 2018 & 27 & 15 & 18 & 60 \\
\hline
\end{tabular}




\section{REFERENCES}

Barrion, A.T. and J.A. Litsinger (1980). Taxonomy and bionomics of spiders in Philippine rice agroecosystems. Foundation for future biological control of effort. Paper presented at $11^{\text {th }}$ Ann. Conf. Pest Control, Council of the Philippines, Cebu City, Philippines, April, 23-25.

Carter, P.Y. and A. L. Rypstra (1995). Topdown effects in soybean agroecosystems: Spider density affects herbivore damage. Oikos, 72:433-439.

El-Nabawy, E. M., K. Tsuda, Y. Sakamaki, A. and Y. Ushijima (2016). The effect of organic fertilizers and flowering plants on sheet web and wolf spider populations (Araneae: Lycosidae and Linyphiidae) and Its importance for pest control. J. Insect Sci.16(1): 18-25.

Greenslade, P.Y. M. and P. Greenslade (1983). Ecology of soil invertebrates In: (Soils: An Australian Viewpoint of soils, CSIRO): 645-669.

Hendawy, A.S. and H.A. Abul-Fadl (2004). Survey of true spiders community and its response to chemical and organic fertilizers in the Egyptian corn fields. Egyptian J. Biol. Pest Control,14 (1): 231-235.

Mansour, F. and W.H. Whitcomb (1986). The spiders of a citrus grove in Israel and their role as biocontrol agents of Ceroplastes floridensis (Homoptera: Coccidae). Entomophaga, 31:269-276.

Mansour, F., D. Rosen and H.N. Plaut (1980). Evaluation of spiders as biological control agents of Spodoptera littoralis larvae on apple in Israel. Acta Oecol., 1:225-232.

Mickhail, W.Z.A. (1993). Effect of soil structure on soil fauna in a desert Wadi in Southern Egypt. J. Arid. Environ, 321-331.
Nentwig, W. (1987). The prey of spiders . pp: 249-263. In Ecophysiology of spiders (W. Nentwig. ed.). SpringerVeriag, Berlin.

Oraze, M.J. and A. Grigarick (1989). Biological control of aster leafhopper (Homoptera: Cicadellidae) and midges (Diptera: Chironomidae) by Pardosa ramulosa (Araneae: Lycosidae) in California rice fields. J. Econ. Entomol., 82:745-749.

Riechert, S.E. and K. Lawrence (1997). Test for predation effects of single versus multiple species of generalist predators: Spiders and their insect prey. Entomol. Exp. Appl., 4:147-155.

Rizk, M.A., M.M. Ghallab, N.H. Habashy and S.A. Allam (2005). Effect of acaricides on some non-target soil fauna in cucumber fields in Fayoum Governorate., Egypt. Egypt. J. Agric. Res., 83 (1): 293-299.

Sallam, G.M. (2002). Studies on true spiders in Egypt. Ph.D. Thesis, Fac. Agriculture. Cairo Univ., 144 pp.

Slingsby, D. and C. Cook (1986). Practical ecology, London, MacMillan, pp. 213.

Southwood, T.R. and P.A. Henderson (2000). Ecological methods. Blockwell Science Ltd. Oxford: $\mathbf{5 7 4}$ pp.

Sunderland, K. (1999). Mechanisms underlying the effects of spiders on pest populations. The Journal of Arachnology, 27: 308-316.

Wise, D. H. (1993). Spiders in Ecological Webs: Cambridge Studies in Ecology.

Young, O. P. and G. P. Edwards (1990). Spiders in the United States field crops and their potential effect on crop pests. J. Arachnol., 18:1-27.

Young, O. P. and T. C. Lockley (1985). The striped lynx spider, Oxyopes salticus (Araneae: Oxyopidae), in agro ecosystems. Entomophaga, 30 :329346. 
تواجد العناكب الحقيقية المرتبطة بنباتات القمح فى محافظتي القليوبية وبني سويف

حسنية عبد الفتاح عفيفي علوان

معهز بحوث وقاية النباتات - مركز البحوث الززاعية - الاقى - جيزة - مصر الفيفي

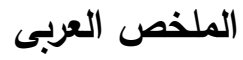

يعتبر محصول القصح من المحاصيل الاستراتيجية فى مصر وتعتبر العناكب الحقيقية واحدة من أهم الأعداء

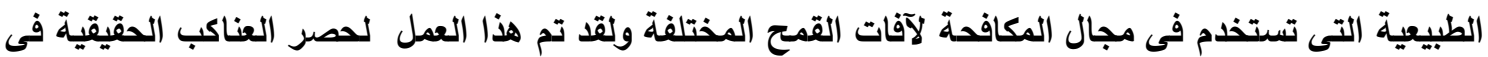

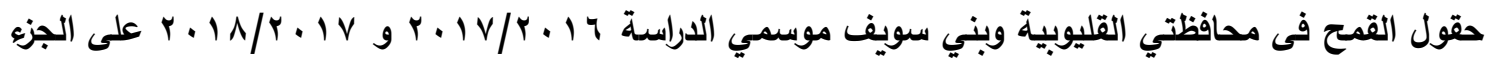
الخضري أو فى التربة المجيطة بالنباتات.

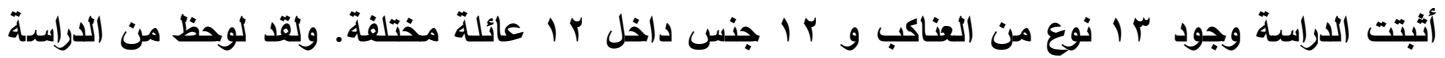

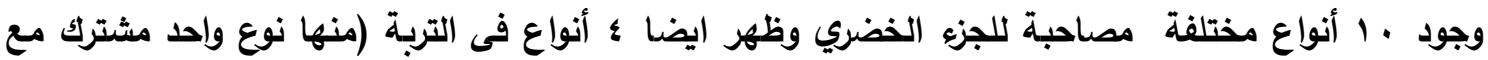

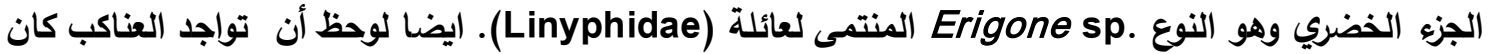

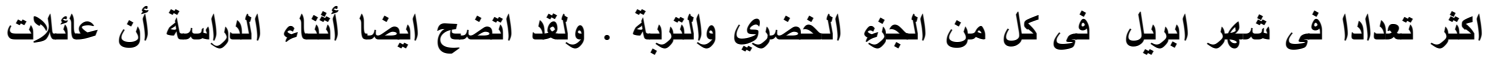

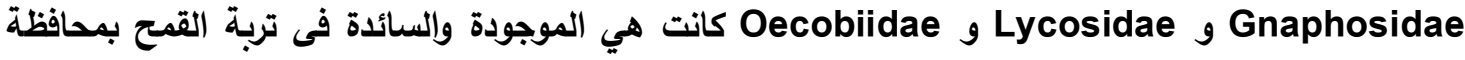

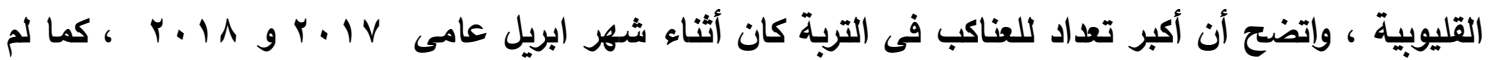

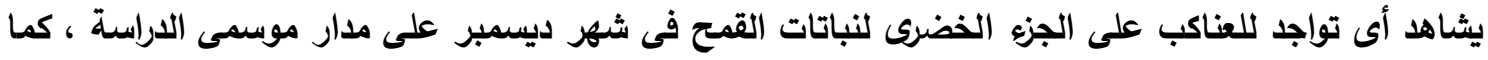

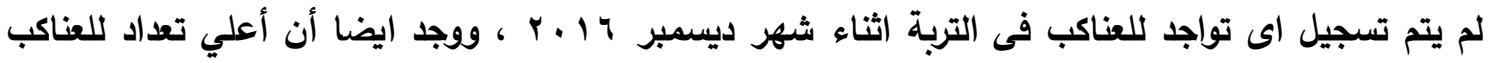

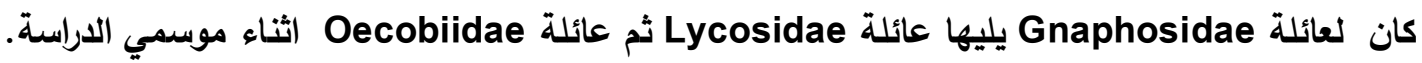


